\title{
Research Paper A case study on economic analysis of marketing and price spread of apple fruit in Kashmir Valley of J\&K state
}

\section{FARHEEN NAQASH, NAVEED HAMID AND DINESH K. KAPILA}

See end of the paper for authors' affiliations

Correspondence to :

\section{NAVEED HAMID}

Division of Agricultural Economics and AgriBusiness Management, SKUAST-J, CHATHA (J\&K) INDIA

Email : bhatnaveedbhat@ gmail.com
Paper History :

Received : 02.05.2017;

Revised : 23.08.2017;

Accepted : 30.08 .2017
Abstract : The study was carried out in the Baramulla district of the Kashmir valley. Apple being main fruit in the district has predominant position in area, production and productivity. Both primary and secondary data was analyzed to interpret the results for this study. Primary data was collected from the 70 sample respondents from a cluster of 6 villages delineated from the Pattan zone along with market functionaries and other important players of value chain. The secondary data was collected from the relevant secondary sources. The studies revealed that majority of the farmers were marginal farmers with upto 2 hectares of land under apple orchards. Cost of apple cultivation works out to be Rs. 206730 per hectare with net returns to the tune of Rs. 496395 per hectare. The study of marketing of apple identified five marketing channels and the channel 1 viz., Producer-Whole seller/Commission agent-Retailer-Consumer, was the major route for apple trade as more than 30 per cent of the farmers produce was marketed through this channel. Marketing efficiency was found maximum (0.68\%) in this channel for the obvious reason as it involves less number of intermediaries. The establishment of Terminal market of Sopore proved a major facilitator in the marketing of apple in the study area. The study of marketing of apple identified five marketing channels and the channel 1 viz., ProducerWholeseller/Commission agent-Retailer-Consumer, was the major route for apple trade as more than 30 per cent of the farmers produce was marketed through this channel. Marketing efficiency was found maximum $(0.68 \%)$ in this channel for the obvious reason as it involves less number of intermediaries. The establishment of Terminal market of Sopore proved a major facilitator in the marketing of apple in the study area.

KeY Words : Apple, Production, Marketing, Terminal market, Consumer, Marketing efficiency

How To Cite This PAper : Naqash, Farheen, Hamid, Naveed and Kapila, Dinesh K. (2017). Acase study on economic analysis of marketing and price spread of apple fruit in Kashmir Valley of J\&K state. Internat. Res. J. Agric. Eco. \& Stat., 8 (2) : 440-447, DOI : 10.15740/HAS/IRJAES/8.2/440-447. 